\title{
Redefining Development and Reclaiming Subaltern Space: Arundhati Roy and the Post-Developoment Critique Of Indian Modernity
}

\author{
Somraj Banerjee \\ (Burdwan, West Bengal, India)
}

\begin{abstract}
In this postcolonial progress-philic age, "progress" in India (and in many other parts of the world) has come to acquire a special meaning which invokes increased marginalization of the already marginalised sections of society, realised through well-orchestrated acts of displacement, insufficient rehabilitation and relentless brutalization of rivers, forests, hills and its indigenous inhabitants. However, all this is done in the name of the "greater common good" with the professed intention of benefitting the entire nation in general and, the poor and the vulnerable in particular. However, in practice, such developmental drives have shown a completely different face proving grossly "ecocidal" and enormously destructive to indigent humans. Development projects of this nature, which include big dams and aggressive mining industries, have brought unforeseen miseries of unimaginable magnitude to the poor tribal populations and the dalits who are systematically disenfranchised, uprooted, displaced and just left to die. These subaltern social groups which invariably have to bear the brunt of the state-sponsored developmental discourse-concretized in behemoth-like projects- have largely disappeared into the irredeemable anonymity of history. Arundhati Roy, in a series of cerebral and polemical essays, has not confined herself to a cosmetic exploration of their plight. She has endeavoured to move beyond the sketchy generalities, the schematic formulations and has tried to reclaim the largely encroached space of these subaltern groups who are hardly heard and even less understood. In this paper I try to show how in the post-developmental (or, anti-developmental) mode, Roy contests and denudes the largely misleading state-backed development discourse, bolstered and seconded by a highly motivated corporate-sponsored cornucopian narrative.
\end{abstract}

Keywords: Big Dam, Displacement, Maoist Insurgency Mining, Post-Development (or, Anti-Development) Theory, Progress, Subaltern, Tribal Population

\section{Introduction}

In this paper, I shall engage with three socio-political prose pieces by Arundhati Roy namely, "The Greater Common Good" (from, The Algebra of Infinite Justice), "Road to Harsud" (from, An Ordinary Person's Guide to Empire) and, "Mr Chidambaram's War" (from, Broken Republic) all of which strike the tenor of postdevelopment (or, anti-development) theory championed by the likes of Ivan Illich, Gustavo Esteva, Arturo Escobar, James Ferguson, Ashis Nandy, Majid Rahnema, Vandana Shiva et al. All these social commentators look through the illusory developmental discourse, the provenance of which can be traced to the West. They observe that our understanding of the very idea of development is constructed, unreal and misleading which willy-nilly is meant to advance the interest of the advanced nations thereby perpetuating the western hegemony. Ashis Nandy rightly points out that the "basic assumption here is that the developed world has automatic right and unavoidable obligation to set the pace for the underdeveloped, for what the developed are today, the underdeveloped will become tomorrow, either through their skills in imitation (euphemistically called diffusions of innovations or transfer of technology) or through the generosity of the wealthy and powerful (euphemistically called aid)." [1] This feeling of intense need for development, therefore, has to be an adopted and unreal notion which Janus-like seems to be double faced, representing two aims-one professed and the other, real. The professed aim of development smacks of benevolence as it talks about "benefit for all". However, it hides a grim and cruel reality. Arundhati Roy, quite in keeping with the post-developmental school of thought, exposes this reality and brings to the forefront the unspeakable and limitless exploitation that the State subjects the helpless indigent people to in its mad pursuit of "progress" and "development".

In the immediate aftermath of independence in the year 1947, India very enthusiastically ushered in an age of development which was seen as a munificent gift of modernity. Various developmental projects were conceptualised and introduced with the professed aim of uplifting the poor masses of the country and strengthening the nation as a whole. Soon "Dam building grew to be equated with Nation building". [2] This infused a fresh lease of energy in our policy-makers who took to the task with such immense ferocity that today "we have 3,600 dams that qualify as Big Dams, 3,300 of them built after Independence. Six hundred and ninety- 
five more are under construction. This means that forty per cent of all the Big Dams being built in the world are being built in India. Yet one-fifth of our population does not have safe drinking water and two-thirds lack basic sanitation." [3] In the span of a few lines, Roy with deft strokes has exposed the basic paradox, the cruel contradiction that underprops the State-sponsored discourse of "development". Such "development" has of course not come free. Building and operationalizing behemoths which we call "Big Dams" have entailed forceful confiscation of land, water, forest from the poor only to fatten the pelf-rich coffers of multinational companies which invest in such projects with understandable alacrity. The huge reservoirs of these dams sweep across large areas of land leaving the hapless men homeless and destitute. From the ecological perspective too, building of dams appears to be suicidal once we confront the fact that "They lay the earth to waste. They cause floods, waterlogging, salinity, they spread disease. There is mounting evidence that links Big Dams to earthquakes." [4] Roy, here, observes that in the West, the myth of development surrounding the idea of big dams has been shattered in the face of overwhelming evidence which thoroughly discredits them and delinks any hope of a good future from them. The shutting down of the dam-building industry in the first world has prompted it to ship the industry to the third world "in the name of Development Aid along with their other waste, like old weapons, superannuated aircraft carriers and banned pesticides." [5] We may very easily add banned drugs, discarded forms of entertainment, discredited social values and many others to the list. The postcolonial anger in Roy's disturbed voice is very much palpable, here. Partha Chatterjee has argued that "through the twentieth century, the process of economic and strategic control over foreign territories and productive resources was transformed from the old forms of conquest and occupation to the new ones of informal power exercised through diplomatic influence, economic incentives, and treaty obligations. A debate that was always part of the nineteenth century discourse of imperialism-direct rule or informal control-was decisively resolved in favour of the latter option." [6] This is validated by Ashis Nandy's observation that "development, modern science and colonialism are not parallel processes, but mutually potentiating forces defining a common domain of conscious-ness " [7]

Arundhati Roy flags well-authenticated figures which underscore the practical and moral unviability of big dams. She points to the fact that "over the last fifty years, India has spent Rs 87,000 crore on the irrigation sector alone. Yet there are more drought-prone areas today than there were in 1947. [8] This of course is loss of national wealth on an inconceivably high scale. Moreover, this has gratuitously precipitated the displacement of fifty six million people. [9] These men and women have no place in their country's history given the fact that the government has no official record since presumably, "most of the displaced are the non-people, the adivasis, and the Dalits" who simply count for nothing. [10] They migrate to the cities as ecological refugees where they can have no chance of a proper housing given the exorbitant pricing of urban metropolitan spaces. They soon get sucked into the vortex of ghettoization in their own tottering shantytowns. In absence of proper municipal sanction, these shantytowns always stand a chance of being decimated on a moment's notice, even if only to make room for the ever-expanding metropolis and its centres of luxury. These displaced people soon lose "touch with their past, their inherited skills and environmental sensitivities (the ecology of resettlement area being usually different)". [11] With so much of emotional and cultural shock, and financial vulnerabilities, these men often get criminalised and are known to have participated in acts of rioting and arson. [12] In high-table talk, these men however account for "collateral damage" that cannot be helped if the State is to keep the juggernaut of "progress" and "development" rolling. Overnight, they become the "no-where men" of the land, ready to vanish.

All these well-established facts of course did not deter the state from conceptualizing and implementing the Sardar Sarovar project on the river Narmada which eventually handsomely matched the infamy of Big Dams. This, however, met with massive popular protest which gave birth to the NBA or, the Narmada Bachao Andolan (Save Narmada Movement) which drew in its folds prominent members of civil society including the Gandhian social activists- Medha Patkar and Baba Amte, and Himanshu Thakker, Shripad Dharmadhikary, Arundhati Roy et al. Roy records the genesis and the total story of the NBA in her essay titled"The Greater Common Good". Soon, the Sardar Sarovar project, like almost all the other projects of its ilk, brought forward glaring misconduct on the part of the State. Roy states them in her incomparable style: "The $\$ 450$ million loan for the Sardar Sarovar projects was sanctioned and in place in 1985. The Ministry of Environment clearance (which ideally and legally is supposed to precede the loan) for the project came only in 1987!" [13] Again she notes: "In 1979, the number of families that would be displaced by the Sardar Sarovar reservoir was estimated to be little over 6,000. In 1987, it grew to 12,000. In 1991, it surged to 27,000. In 1992 the Government acknowledged that 40,000 families would be affected. Today, the official figure hovers between 40,000 and 41,500...According to the NBA, the actual figure is about 85,000 families-that's half a million people." [14]

Sifting through facts and figures, Roy reaches the mathematical conclusion that the Sardar Sarovar Projects which will cost around "Rs 44,000 crore" will end up "consuming more electricity than they produce!" [15] Such self-defeating inevitability did not stop the State from going the extra mile to get it done. 
Similar is the story of the Narmada Sagar Dam, the tale of which Roy records in her essay-"The Road to Harsud". The "Harsud" of the title is a 700 year old town in Madhya Pradesh (MP), which's slated to be marooned by the reservoir of the Narmada Sagar Dam (sometimes referred to as the Indira Sagar Dam). Roy notes: "In order to irrigate 123,000 hectares of land it will submerge 91,000 hectares! This includes 41,000 hectares of prime dry deciduous forest, 249 villages and the town of Harsud. According to the Detailed Project Report, 30,000 hectares of the land in the Narmada Sagar command was already irrigated in 1982." [16]

The establishment, in the mean time, has arrogantly ignored the warnings issued by the experts from The Indian Institute of Science (IISC), Bangalore, Review Committee of the Ministry of Environment and the Wild Life Institute of Dehradun. It has also been suggested that "30,000 families will be uprooted from their homes. About 5,600 of these families (22,000 people) are from Harsud. Remember, these are 1981 figures." [17] Tragically but predictably, "Not a single family has been resettled according to the NWDTA (Narmada Water Disputes Tribunal Award) or the Madhya Pradesh rehabilitation policy." [18] But the government remains undeterred. Roy blows the lid off the unholy nexus between the State and the foreign funding agencies "beginning of course, with the World Bank, the big private banks and multinational corporations (which) are cruising around, looking for sweetheart deals. But (since) overt privatization has run into bad weather (they have moved away)...From overt invasion to covert insurgency." [19] Ramachandra Guha's observation clinches the argument: "All over the world, large dams are being challenged as 'outdated monuments to an immodest era,' symbols of a centralizing, capital-intensive and environment-insensitive form of development that is no longer acceptable." [20]

“Mr Chidambaram's War”, which appears in Roy's latest book- Broken Republic, deals with rampant mining and deflowering of mineral-rich forests and hills of central India which in recent times have become the hotbed of Maoist insurgency. "The low, flat-topped hills of south Orissa have been home to the Dongria Kondh (a tribe) long before there was a country called India or a state called Orissa. The hills watched over the Kondh. The Kondh watched over the hills and worshipped them as living deities. Now these hills have been sold for the bauxite they contain. For Kondh it's as though god has been sold." [21]-That's how Roy begins the essay and immediately raises the critical issue. These men, therefore, are a part of an inspirited world of nature that has been ruthlessly sacrificed at the altar of profit, marketed as "development". Arundhati Roy records that "the financial value of the bauxite deposits of Orissa alone is 2.27 trillion dollars (twice India's gross domestic product). That was at 2004 prices. At today's prices it would be about four trillion dollars. A trillion has twelve zeroes." [22] Such an astronomical sum is good enough to catch the attention of greedy eyes.

Armed with the same old developmental discourse, the State has quickly rolled its sleeves up and issued a draconian decree to remove the indigenous population of the place only to make way for foreign companies to enter and get their luxurious lives subsidized by the poorest of the poor of this country. Sudden displacement and insufficient rehabilitation push these men into the miasmic darkness of destitution. Roy notes that "They believe that if they do not fight for their land, they will be annihilated. That is why they have taken up arms." [23] For them, resorting to violence is a Hobson's choice. Amartya Sen's observation is relevant enough to be quoted in this context: "Neglect can be reason enough for resentment, but a sense of encroachment, degradation and humiliation can be easier to mobilize for rebellion and revolt." [24] Therefore, it can safely be concluded that years of accumulated injustice (triggered by the State's recalcitrant apathy towards these people) have resulted in unnecessary violence and limitless bloodshed. Roy very quickly scratches the patina of the state-sponsored "development-mantra" and discovers that "Over the past five years or so, the governments of Chhattisgarh, Jharkhand, Orissa and West Bengal have signed hundreds of MoUs with corporate houses, worth several billion rupees, all of them secret, for steel plants, sponge-iron factories, power plants, aluminium refineries, dams and mines. In order for the MoUs to translate into real money, tribal people must be moved. Therefore, this war." [25] This of course is accompanied by "elaborate, if increasingly empty rituals of democratic practice: the (rigged) public hearings, the (fake) environmental impact assessments, the (purchased) clearances from various ministries, the long-drawn-out court cases." [26] The cry for justice thus goes unheard.

The State however drums the virtues of "development"- the be-all and end-all of modern nation state. It argues that the mining industry will substantially contribute to the country's GDP which may then be used for "the greater common good". By a clever sleight of hand, increase in GDP is equated with alleviation of poverty. A large section of westernised middle class, which constitutes a sizeable vote-bank, willy-nilly participates in this Statist conspiracy. A close dispassionate scrutiny, however, debunks such seemingly reasonable arguments championing globalization: “...between 1983 1nd 1990-91, when economic growth rate was about 5.6 per cent, the proportion of Indians living below the poverty line had fallen by 3.1 per cent per year. When, between 199394 and 1997, growth rate shot up to 6.9 per cent per year, the figure went up from 35 to 37 per cent." [27] However, it has become obvious that the ambitious and monetised urban middle classes find themselves in league with this developmental/neo-colonialist agenda since their high-flying professional aspiration has inextricably linked itself with the graph of corporate-capital-fortunes. Hence, the middle classes acceptance of 
development as a panacea for all evils. It is the same section of society which tempers the tenor of mass-media discourse. It has also been pointed out that the urban middle/upper classes' wholehearted espousal of destruction and exploitation of forest resources in the name of development has much to do with the fact that these classes "constitute a substantial and growing market for a variety of forest produce." [28]

Roy, in tune with the post-developmental school of thought, argues that although the champions of "development" opine that GDP growth generates employment and wealth which can rehabilitate displaced people, this simply is untrue. Moreover, such a line of argument invariably overlooks the irreparable damage done to ecology. Again, most of the money generated by the large-scale exploitation of man and his environment "goes into the bank accounts of the mining corporations. Less than 10 per cent comes to the public exchequer. A very tiny percentage of displaced people get jobs, and those who do, earn slave wages to do humiliating, back-breaking work. By caving into this paroxysm of greed, we are bolstering other country's economies with our ecology." [29]

Roy persuasively argues that growth in GDP percentage hardly tells the whole story. Such a growth, when properly examined, is found to be utterly unbalanced, biased and completely unsustainable. While it fails to satisfy the basic needs of the bulk of the population who persistently languish in destitution, it also discounts the enormous cost exacted by the pathological destruction of ecological health which may very soon sound the apocalyptic death knell, indeed. Jayati Ghosh rightly observes that "Commercialization and the greater play of market forces typically operate to increase economic inequalities and the reduction of 'welfare' activities of the developmental state." [30] Since the developmental discourse generated by the "developmental state" can hardly divorce itself from the hegemonic play of instrumentalist market forces, it can never meet the professed end (which is, development for all) by which it seeks to justify its highly questionable means. Like a true postdevelopmental humanist, Arundhati Roy dismisses the Statist position which is given to using words like 'progress' and 'development' interchangeably with the Globalization-centric concepts of "economic 'Reforms', Deregulation and Privatization." She uncompromisingly hits at the fact that "Tens of millions of people have been dispossessed and displaced from their land by floods, droughts and desertification caused by indiscriminate environmental engineering and massive infrastructural projects, dams, mines and Special Economic Zones. All of them developed in the name of poor, but really meant to service the rising demands of the new aristocracy." [31]

\section{Conclusion}

Arundhati Roy in these cerebral and combative socio-political prose pieces has persuasively argued that the local cultural, sociological and personal needs of the subaltern groups remain largely incomprehensible to "development experts" who, however, enjoy boundless powers to radically alter the lives of people they don't understand or empathise with. Roy sees this as a veritable foundation of injustice. Such unnatural participation of foreign players in domestic affairs invariably leads to natural-resource-misappropriation on a massive scale which does not auger well for the entire community. She, therefore, calls for a thoroughgoing pluralization of the dominant developmental discourse thereby making it more fluid, open-ended, accommodative and sensitive to the sentiments and voices from the margin. Roy's post-developmental critique of Indian modernity is also a postcolonial contestation of a foreign discourse that, in more ways than one, seeks to perpetuate the western hegemony in a neo-imperialistic age.

\section{References}

[1] Ashis Nandy, The romance of the state and the fate of dissent in the tropics (Oxford University Press, New Delhi, 2003$), 159$.

[2] Arundhati Roy, The greater common good, in The algebra of infinite justice (Penguin Books, New Delhi, 2002$), 56$.

[3] ibid, 56-57

[4] ibid, 58

[5] ibid

[6] Partha Chatterjee, Lineages of political society: studies in postcolonial democracy (Permanent Black, Ranikhet, 2011 ), 243.

[7] Ashis Nandy, The romance of the state and the fate of dissent in the tropics (Oxford University Press, New Delhi, 2003), 159.

[8] Arundhati Roy, The greater common good, in The algebra of infinite justice (Penguin Books, New Delhi, 2002$), 59$.

[9] Arundhati Roy, The shape of the beast (Viking, New Delhi, 2008), 45.

[10] ibid, 44

[11] Ashis Nandy, Time warps: the insistent politics of silent and evasive pasts (Permanent Black, Delhi, 2002$), 155$.

[12] Madhav Gadgil and Ramachandra Guha, Ecology and equity in (the omnibus) The use and abuse of nature (Oxford University Press, New Delhi, 2000), 68.

[13] Arundhati Roy, The greater common good, in The algebra of infinite justice (Penguin Books, New Delhi, 2002$), 76$.

[14] ibid, 82

[15] ibid, 83 .

[16] Arundhati Roy, The road to harsud, in An ordinary person's guide to empire (Penguin Books, New Delhi, 2006$), 244$.

[17] ibid, 255.

[18] ibid, 249.

[19] ibid, 276-77

[20] Ramachandra Guha, Environmentalism: a global history (Oxford University Press, New Delhi, 2000$), 132$

[21] Arundhati Roy, Mr chidambaram's war, in Broken republic (Hamish Hamilton, India, 2011), 1. 
[22] ibid, 23.

[23] ibid, 8

[24] Amartya Sen, Identity and violence: the illusion of destiny (Allen Lane, India, 2006), 144.

[25] Arundhati Roy, Walking with the comrades, in Broken republic (Hamish Hamilton, India, 2011), 44

[26] Arundhati Roy, Mr chidambaram's war, in Broken republic (Hamish Hamilton, India, 2011), 22-23

[27] Ashis Nandy, Time treks: the uncertain future of old and new despotisms (Permanent Black, Ranikhet, 2007), 98-99.

[28] Madhav Gadgil and Ramachandra Guha, Ecology and equity in (the omnibus) The use and abuse of nature (Oxford University Press, New Delhi, 2000), 154.

[29] Arundhati Roy, Mr chidambaram's war, in Broken republic (Hamish Hamilton, India, 2011), 26.

[30] Jayati Ghosh, Development strategy in india: a political economy perspective, in Sugato Bose and Ayesha Jalal (Ed.), Nationalism, democracy and development (Oxford University Press, New Delhi, 1997), 181.

[31] Arundhati Roy, Listening to grasshoppers: field notes on democracy (Hamish Hamilton, India, 2009), xiv. 